\title{
O significado da educação permanente sob a ótica de enfermeiros da Estratégia de Saúde da Família
}

\author{
Ariana Colombari de Godoi Floresta, Maria Goreth Lourenço Caetano, Pauliana Pimentel Coelho
} Garcia, Deíse Moura de Oliveira

\begin{abstract}
Resumo
A Estratégia de Saúde da Família (ESF) visa a reorientação do modelo assistencial e tem no enfermeiro um dos atores fundamentais para atuar nesta lógica e auxiliar na mudança das práticas historicamente hegemônicas na saúde. Para que tal mudança ocorra faz-se necessário pautar a educação permanente (EP), uma vez que a reorientação do modelo assistencial prediz uma implicação dos profissionais de saúde com os micro-processos do trabalho em saúde configurando a EP como uma ferramenta mediadora das mudanças vislumbradas na prática. $\mathrm{O}$ estudo tem como objetivo compreender o significado atribuído à Educação Permanente por enfermeiros da Estratégia de Saúde da Família de um município de Minas Gerais. Trata-se de uma pesquisa qualitativa realizada com 11 enfermeiros da ESF de um munícipio localizado na Zona da Mata de Minas Gerais. A coleta de dados ocorreu entre março e maio de 2015, por meio de entrevista com questões abertas, sendo interrrompida utilizando o método de saturação teórica. Os dados coletados foram analisados por meio da análise de conteúdo de Bardin e interpretados em consonância com a literatura pertinente à temática. O projeto foi aprovado pelo Comitê de Ética em Pesquisa com Seres Humanos da Universidade Federal de Viçosa, conforme o Parecer $\mathrm{n}^{\circ}$ 909.717, de 09 de dezembro de 2014. Os depoimentos permitiram a emersão da categoria. O significado da Educação Permanente para o enfermeiro da ESF" e de duas subcategorias: "Perspectivas Conceituais" e "A importância atribuída à Educação Permanente". A maioria dos enfermeiros significam a educação permanente na lógica da educação continuada, compreendendo-a como uma capacitação para o serviço realizada de modo pontual e voltada prioritariamente para o aspecto instrumental. Associam-na ainda à participação em cursos oferecidos por instituições, como secretaria de saúde e universidade. Isso reflete que os participantes do estudo não trazem significados coerentes com a proposta da EP, sendo estes muitas vezes associados a capacitação profissional, em detrimento da problematização do cotidiano do trabalho em saúde. Cabe ressaltar que independentemente da concepção que trazem todos atribuem à EP uma importância para a qualificação das práticas de saúde. Os achados desta investigação remetem a necessidade de que a lógica da EP seja efetivada enquanto política inscrita no processo de trabalho em saúde no âmbito da ESF. Neste contexto, há que se pensar em investir na sensibilização dos profissionais de saúde, entre eles o enfermeiro, no sentido de compreenderem a EP como uma atividade que emerge da micropolítica do trabalho em saúde e como a força motriz para o agenciamento das mudanças necessárias para a reorientação do modelo assistencial.
\end{abstract}

Descritores: Enfermagem; Educação Continuada; Saúde da Família. 